\section{Fostering Holocaust Education and Remembrance Culture using Geomedia}

GI_Forum 2018, Issue 2

Page: 193 - 206

Full Paper

Corresponding Author:

katharina.woehs@gmail.com

DOI: $10.1553 /$ giscience2018_02_s193

\author{
Katharina Wöhs, Rafael Paulisc hin-Hovdarand Anna Gatterbauer \\ University of Salzburg, Austria
}

\begin{abstract}
This paper deals with the integration and promotion of spatial citizenship and publicpartic ipation GIS in educ ation - especially in geography lessons - to maintain and improve Holocaust Education. Because of the political shift towards the right in Europe during recent years, the act of mainta ining and promoting Holocaust Education is more important than ever. Therefore, it is crucial for schools to educ ate young students in terms of what the Holocaust was, what happened, how they are connected to the topic (for example through the history of their surroundings), and, most importantly, what can be done in order to prevent such things happening again in the future. Furthemore, the Austrian Curriculum for Secondary Schools (BGBI, 2016) states that one of its highest educational goals is the direct confrontation of a student's individual identity with the promotion of respect, tolerance and solidary. With this aim in mind, this paper deals with the 'places of resistance in Salzburg' project, in which students participate in the expansion of an online archive and the creation of an online tour, both of which will be available for the public. The approach builds on resistance as one part of Holocaust Education: resistance against (local) atroc ities, such as the violation of values of tolerance, respect or even human rights, might be truly diffic ult, but it is possible - and even was so during WWII.
\end{abstract}

\title{
Keywords:
}

Holocaust Education, PPGIS, archival work, Places of Remembrance, Remembrance Culture

\section{Introduction}

At a time of widespread digitalization, geomedia offer new opportunities for educational but also for historical and archival work, and, therefore, also for Holocaust Education. Digital tools and archives will become especially important for Holocaust Education, as few witnesses of WWII are still alive today. In addition, due to the rise of right-wing political parties in Europe, Holocaust Education is of the highest relevance in an educational context. Concerning the current political situation, and (relatedly) the technological situation (i.e. web entries and fake news), the project should also promote critical thinking and the critical use of digital content. The approach aims to combine the two elements of geomedia and digital, archival information: the use of geomedia will provide an interface between classical 
Holocaust Education in schools and raise of awareness of instances both of resistance and of cruelty during the Holocaust, in the city of Salzburg. A public wiki and an online map will serve as an interface to which students can add missing information. Their main aim will be to fill in gaps in the history of places and communicate the information to the public. Students will work with postcards containing a QR-code, developed, designed and provided by KZ-Verband Salzburg. With the help of the QR code and the sources it provides, students will create new content in the SalzburgWiki, and an online tour through the city of Salzburg.

This paper elaborates on Holocaust Education and Places of Remembrance within an educational context. Hellmuth (2016) serves as a basis for the different types of places of memory. Ohl and Neeb (2012) provide the foundation for the educational benefit of the project. The learning environment and a short exemplary analysis are then presented. Schellenbacher's (2017) approach to the digitalization of archival work is complemented by the independent work of students who not only use a digital archive, but also expand it. To sum up, as Figure 1 shows, the project's aims are education and awareness-raising in the subject of local Holocaust incidents and its places of remembrance, achieved through the use of geomedia in a school context (i.e. in school history and geography lessons).

\section{Education and Raise of Awareness}

\section{Holocaust and Places of Remembrance} Geomedia

\section{SCHOOL}

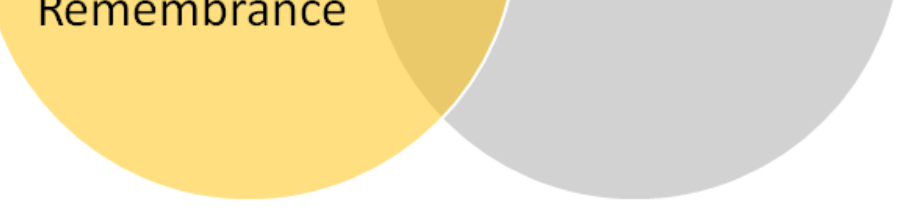

Figure 1: The 'Integration of Geomedia in Holocaust Education' concept (the author, 2018) 


\section{Holocaust Education and Places of Remembrance}

\section{Holocaust Education}

Holocaust Education is a highly significant issue in countries such as Austria or Germany which teachers have to treat sensitively, since students may have diverse prior knowledge, and/or diverse attitudes and values regarding the Holocaust (Ehmann et al., 1995). Holocaust Education as such has no clear definition (Matthes \& Meilhammer, 2015: 10). It is referred to by such formulations as 'teaching about the Holocaust', 'teaching the Holocaust', 'studying the Holocaust' and 'learning about the Holocaust', or is associated with educational aims and methods addressing equality, human rights, anti-racism or the development of tolerance (Sigel, n.d.: 61). Overall, the term and its functions are not subject-bound, since it refers to general education in ethics, inside and outside schools (ibid.). In our approach, however, the focus will lie especially on acts of resistance. It should teach that resistance was an option, even during WWII.

Although only a minority of people still deny that concentration camps existed at all, and, therefore, believe in the Ausschwitz-lie (Ehmann et al., 1995), it is of utmost importance that students should comprehend what happened during and even before the years 1938-1945. The persecutions and mass murders during the Holocaust of Roma and Sinti people, of opponents of the Nazi regime, of homosexual and disabled people, and of all people categorized as 'Jews' based on the Nuremberg Laws, are an undeniable truth in the history of Austria (and other countries), and they should never be forgotten or repeated (Friedländer, 2008). This is one reason why it is important to teach both the undeniable events of the Holocaust and that there were forms of resistance.

In order for students to acquire an understanding of events during WWII, and their connection to Austrian history, it should be every teacher's aim to find a balance between an abstract analysis of the subject and a direct visualization. This can be done by visiting places of remembrance. In Austrian schools, this often takes the form of visits to former concentration camps. While these visits are a highly formative experience for students, they can also be seriously emotional and psycho-socially demanding (Ehmann et al., 1995). They can require a very skilful pedagogical-psychological approach on behalf of the teacher dealing with Holocaust Education, and therefore one might think of other options or places to visit.

In this paper, we present how awareness of acts of resistance within the student's immediate surroundings (i.e. the city of Salzburg) can be raised, and how students can participate in developing historic archives. The idea of the project ties in with articles 2, 3, 4, 5 and 6 of the Stockholm Declaration (2000) of the International Holocaust Remembrance Alliance (IHRA), signed by 31 countries, including Austria and German, to create awareness not only of what happened to the victims but also of the fact that resistance was possible, and indeed actively pursued. Article 2 states that 'The selfless sacrifices of those who defied the Nazis, and sometimes gave their own lives to protect or rescue the Holocaust's victims, must also be inscribed in our hearts [...],' and article 3 says that 'Together we must uphold the terrible truth of the Holocaust against those who deny it.' Article 3 states, further, that 'We must strengthen the moral commitment of our peoples, $[\ldots]$ to ensure that future generations can understand the causes of the Holocaust and reflect upon its consequences.' This also ties in 
with article 4, which pledges to 'strengthen our efforts to promote education, remembrance and research about the Holocaust', and article 5, which once more highlights the significance of studying and sharing information about the Holocaust and suggests how the future generations mentioned in article 3 can gain an understanding of what happened:

'We share a commitment to encourage the study of the Holocaust in all its dimensions. We will promote education about the Holocaust in our schools and universities, in our communities and encourage it in other institutions.'

In addition, Article 6 of the Stockholm Declaration is particularly important for the approach of the lesson plan that we present in this paper, as it focuses on the victims of the Holocaust and the people who showed resistance even when such actions endangered their own lives:

'We share a commitment to commemorate the victims of the Holocaust and to honour those who stood against it. We will encourage appropriate forms of Holocaust remembrance, including an annual Day of Holocaust Remembrance, in our countries.'

Thus, the lesson plan aims not only to fulfil the objectives of the overall Austrian Curriculum for Secondary Schools, but also to tie in with the articles of the Stockholm Declaration.

\section{Places of Remembrance}

One way to teach the Holocaust on a regional, history-related basis is through on-site learning, i.e. by visiting places of remembrance with students. Such places could be monuments, buildings or public places connected to events during the Holocaust. Monika Sommer, the manager of the House of History in Salzburg, gave a clear statement on why such places of remembrance are so important: it is of utmost importance that we keep constructing places of remembrance, as the generations to come will have no contemporary witnesses (Ruep, 2018). Therefore, our aim is not only to encourage student visits to places of remembrance, but also to develop new ways of providing public access to such places.

\section{Types of Places of Remembrance}

Hellmuth (2016) organizes places for external educational visits into three categories: (1) places which remind the visitor of past events, such as churches, monuments and places of remembrance. Note that even places that only remind the visitor of events (the incidents did not take place at the exact location) fall into this category; (2) historic sites where historic testimonies are collected, such as museums or archives; (3) simulations or reconstructions of historic events that students can watch. In a word, teachers and students have many possibilities for extra-school learning.

The focus of the approach presented in this paper is on the first two categories. Firstly, students create an online tour of historic places in the city of Salzburg, including buildings, monuments and public places. Second, they not only visit a place where historic testimonies are collected, but also help to develop one by adding information to an existing archive, spatializing this information on a map, and by creating an online tour available for the public. Through this spatializing act, the students attach new, or forgotten, meanings to specific locations - meanings that might change the perception of some people or at least provoke 
them to think about what happened in those places. As a result, the place will evoke different thoughts (e.g. of the memories which are spread), and, hopefully, create fresh awareness of events. However, the students' attention should be drawn not only to the atrocities committed at the particular places; they should also be made aware of the acts of cruelty that took place in their immediate surroundings, as well as of the acts of resistance towards them. Thus, in the current political context, when certain perpetrators trample on human rights, the aim of providing an understanding of the possibility of showing resistance is ensured. At the same time, by dealing with the atrocities against which resistance was shown (as described in the QR sources), the lesson design should guarantee that there is no danger of slipping into a revisionist narration of 'Opa war kein Nazi' ('Grandpa was not a Nazi'), as described in Welzer, Mollner and Tschuggnall (2002).

\section{Educational Benefit}

Visiting places of remembrance offers many advantages for students' as well as adults' learning processes. First, and most importantly, this is on-site learning. On-site learning has had a long tradition in geography lessons and is, nowadays, mainly focused on cognitive and constructive concepts (Ohl \& Neeb, 2012: 259). The cognitive approach focuses on how the internalization process of learning works - from the input, to how it is processed in the brain, to how the newly-acquired knowledge is represented, and then influences future actions or thoughts (ibid.: 265). Overall, on-site learning as one form of cognitive learning is intended to be a holistic form of action-orientated learning, meaning that the students are exposed to a phenomenon in a situation that is as close as possible to a real-life situation (ibid.: 264-65).

Compared to the holistic, cognitive approach, the constructive approach to on-site learning focuses, rather, on a subjective construction of knowledge based on pre-knowledge, values, personal background and, most importantly, interaction and dialogue with others (Ohl \& Neeb, 2012: 267). These interactive and social dialogues form the basis for the construction of one's own perspective on a topic and allow different positions (ibid.).

Throughout the years, both forms of on-site learning have proven to be effective forms of teaching/learning. In sum, their effect is higher motivation for learning, as the objects become tangible and real, which leads to an advanced ability to remember the input, as students are immediately engaged with the topic (Ohl \& Neeb, 2012: 260). In addition, personal involvement in the examination of sites or problems plays a crucial role in the learning process (ibid.). Ohl and Neeb distinguish between less involvement (which is generally cognitive-based), where students visit places for reasons of visualization and demonstration, and active involvement (which is more constructive-based), where they actively work on a problem or a (research) question (ibid.: 262). In sum, the more motivated and engaged the students are during the learning process, the easier it will be for them to remember, learn and expand their knowledge or perceptions about a topic. 


\section{Geomedia-based Learning Environment}

In this digital era, almost any information, including archival material, can be found on the internet, which offers new opportunities for Holocaust Education - not only for schools, but also for any individual who wants to share his or her knowledge. The internet itself provides ubiquity and an immense storage capacity for information, which creates new possibilities for Holocaust Education.

The learning environment for this project's sequence of activities on Holocaust Education is geomedia-based and builds on the concepts of 'Activist Citizenship Education' (Gordon, Mitchel \& Elwood, 2016) and 'Spatial Citizenship Education' (Gryl \& Jekel, 2012). Both argue for the active involvement of citizens/pupils in local, spatial politics. In addition, the visualization of right-wing extremism for the purpose of raising public awareness (Lehner, Jekel \& Vogler, 2017) provides a theoretical basis for the ideas presented here.

The project on acts of resistance in Salzburg uses geomedia. These include an online archive, the SalzburgWiki (which stores location-related information), and ArcGIS online (where the students spatialize their findings).

The end result of the project should be that

(1) through the operating mode of the Wiki and ArcGIS online, information becomes available for every person who searches by location.

(2) the information is communicated to the public.

(3) the map in ArcGIS online serves as an online tour through the city of Salzburg and its places of resistance, providing information on the history of local resistance, its victims, and the people who stood against Hitler and his regime, all available both inand outside the classroom.

\section{Digital Archives (1): SalzburgWiki}

Focusing on the archival use of the internet, Schellenbacher (2017) presented one example for geomedia-based archival work in Austria in his project Memento Vienna, which maps 'the history of the city centre and its former residents' (p. 14). His project is an application full of digitized archival and historic information on the immediate surroundings of people in Vienna. The project that is the subject of this paper, places of resistance in Salzburg, goes one step further in terms of archival work, following an active-participation approach as described in Scheidig (2015: 249-50), where students create or correct wiki-entries themselves. Students compare the information for a place given in a source with which they are provided (Cards) on the one hand to the information given in an historical, local Wiki the SalzburgWiki. In cases where the Wiki lacks information, students should add the new information about acts (and reasons) of resistance in Salzburg to the locations' histories. Thus, students actively develop and expand archives themselves and write histories of places.

As described in Scheidig (2015), this form of learning is particularly intensive and boosts critical reflection on the use of sources, as students will be very close to experiencing what a lack of information can mean. In this case, it could mean that whole years of atrocities have 
been swept under the carpet. In addition, given how common and easy it is to enter an unknown name or phrase, or a place someone wants to visit, into a Wiki, the project demonstrates how the students' work could influence the public (Scheidig, 2015: 249). Nevertheless, however useful this may seem, one must not forget that the information added might get deleted, for whatever reason. But even if the information is deleted, the deletion could serve as a trigger for reflection on why someone would delete it, and so the students have a new reason to think critically.

Be this as it may, the focus of this paper is to offer new, far-reaching possibilities for the integration of geomedia in Holocaust Education through the generation of a new history of places, produced by students themselves. It is not - yet - about the maintenance of the archive.

\section{Digital Archives (2): ArcGIS online}

ArcGIS online is a cloud-based GIS mapping platform which allows students to localize and spatialize their findings. The goal of the project is that the students create a map comprising all locations they have been working on. The map itself should show the locations and provide information about them. To do this, students have to interlink the locations of their map, the newly-generated archives (webpages of SalzburgWiki), and their sources (website of $\mathrm{KZ}$ Verband's cards). Besides providing geodata and archival information, they should also include pictures of the places. The result should be a map which serves as an online tour guide through the city of Salzburg and its places of resistance. Furthermore, the map will also be available for the public. Thus, the information is not only shared within the classroom, but also communicated to the outside world.

\section{Sources}

The fundamental basis of the lessons are the postcards of the 'Ansichtssache' project, created by KZ-Verband Salzburg. KZ-Verband is a non-profit organization founded in 1945 by members of resistance and victims of Fascism during WWII. It is independent of any political party. Its aim is to preserve the legacy of resistance to the dictatorship of Austrofascism and the NS-Regime in order to support a free, democratic and independent Austria. The organization's aims were expanded to include the preservation of the legacy of resistance in Europe more widely against the mass-murders and policy of Hitler in order to support a free and democratic European continent. In addition, KZ-Verband cares for the victims of this persecution (KZ-Verband, 2012).

KZ-Verband's 'Ansichtssache' project is a collection of postcards which show places of resistance in Salzburg in a fairly objective way, and each picture includes a QR code. Once scanned using an app on their smartphones, the QR code leads the students directly to a website, which contains information about the specific location. This information includes short overviews of acts of resistance and atrocities committed (in Salzburg) during WWII, performed at the place in question. In addition, the students find a list of sources they can use for further investigation.

The cards are at the heart of the first step of a four-level lesson plan, and the whole project builds upon them. 


\section{Lesson Plan}

The lesson plan is designed for students in their fourth or fifth year of upper secondary education (i.e. in their final years of secondary education), as it requires a variety of advanced skills. The plan itself is divided into four major steps: 'Card', 'Archive', 'Wiki Work' and 'Tour'.

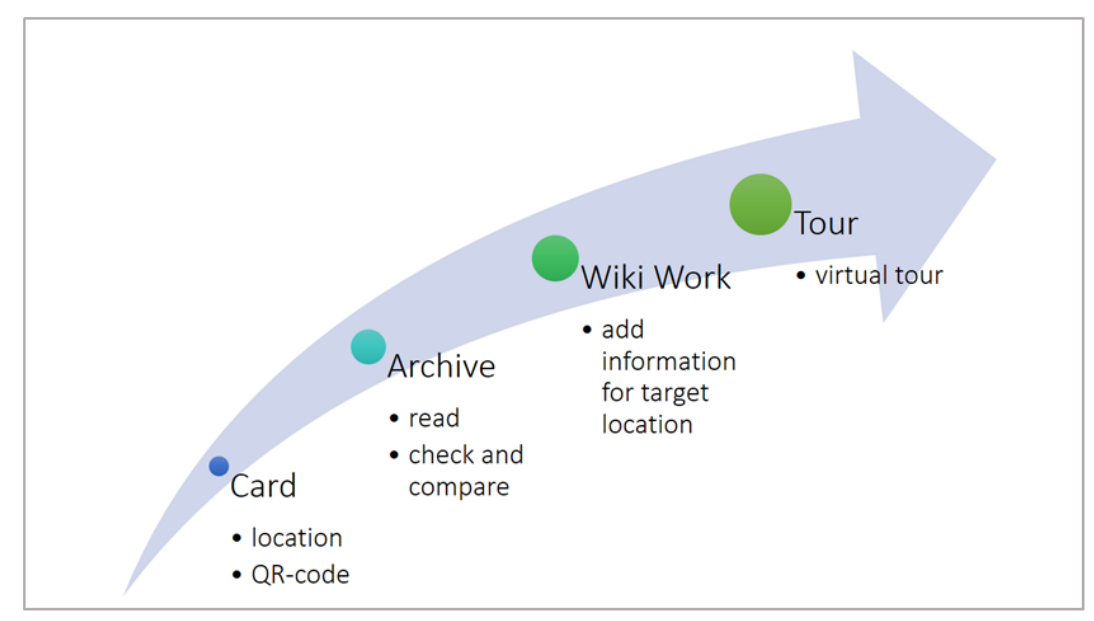

Figure 2: Lesson plan (the author, 2018)

Table 1: Lesson Plan (the author, 2018)

\begin{tabular}{|l|l|}
\hline & $\begin{array}{l}\text { Pre-knowledge (of topic and use of ArcGIS online) from prior history and geography } \\
\text { classes. }\end{array}$ \\
\hline Lesson 1 & $\begin{array}{r}\text { Material: Cards, Smartphone or Laptop, pen and paper } \\
\text { 1. }\end{array}$ \\
2. & Teacher introduces students to new topic \\
& Figure 3)
\end{tabular}




\begin{tabular}{|c|c|}
\hline Lesson 2 & $\begin{array}{l}\text { Material: Cards, Smartphone or Laptop, pen and paper } \\
\text { 1. Teacher informs students that they will add the missing information in the } \\
\text { wiki } \\
\text { 2. Teacher informs students about how to use the SalzburgWiki as editor } \\
\text { 3. Students add missing information to the SalzburgWiki and, therefore, actively } \\
\text { write histories of places, which can be read by anyone who reads the wiki } \\
\text { entry on the target location } \\
\text { 4. Before the lesson ends, teacher informs class about an online tour they will } \\
\text { create in the next lesson. } \\
\text { Plus: Students, should prepare a short presentation (approximately } 5 \text { minutes) } \\
\text { in which they present their location, the history of the place in terms of } \\
\text { resistance, and give a short overview of what they had to add or what was } \\
\text { already mentioned in the Wiki } \\
\text { Teacher asks students to review their ArcGIS online material from previous } \\
\text { lessons }\end{array}$ \\
\hline $\begin{array}{l}\text { Lesson } 3 \\
(+4)\end{array}$ & $\begin{array}{l}\text { Material: Computer lab/ Laptop, notes from previous lessons } \\
\text { 1. Class to be held in computer lab } \\
\text { 2. Teacher instructs all student groups (one per location) to create a layer in } \\
\text { ArcGIS online where they should spatialize their findings } \\
\text { 3. Students include link to wiki and its new content, plus link to source (QR- } \\
\text { website), and add further information (place name, short description, } \\
\text { pictures) to target location } \\
\text { 4. Together, students create ONE map, where they add all layers containing all } \\
\text { places of resistance and their information } \\
\text { 5. Students take part in the virtual tour and each group presents their findings } \\
\text { 6. Questions and discussion after tour; critical reflection } \\
\text { 7. Tour-map should be integrated into the Wiki }\end{array}$ \\
\hline
\end{tabular}

\section{Illustrative example}

The following sample analysis serves as a guideline for what the real in-class work should look like.

First, students discuss the location of the picture and suggest how they would connect the location to the topic of resistance during WWII.

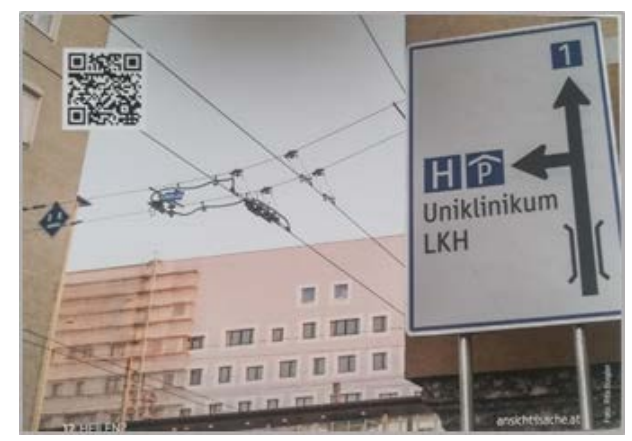

Figure 3: 'Landeskrankenhaus Salzburg' (Salzburg hospital) (KZ-Verband 2017; Photo: Rita Bürgler) 


\section{Wöhs et al}

Next, the students begin to do research on the location. As Figure 4 shows, nothing about resistance at the 'Landeskrankenhaus Salzburg' (Salzburg hospital) is mentioned in the Wiki (as at 01.02.2018). However, information on the website which opens as soon as the students scan the QR code (see Figures 5 and 6) includes evidence for resistance at this very location. The reader learns that nuns usually assisted surgeons in procedures to sterilize people, but also that the nuns of the Order of St. Vincent of Paul were instructed to refuse to assist in such procedures. It does not say exactly how many nuns resisted, but that Anna Berta von Königsegg, the nuns' supervisor, was a resistant and that she was the one who gave the order. Sterilization, which affected 5,000-10,000 people in Austria, was part of the Nazi's 'racial hygiene' programme (Hofinger, 2016).

\section{Information: Wiki}

Von 1891 bis 1899 wurde das erste Kinderspital, und von 1897 bis 1899 die "Geburtshilfliche und Frauen - Abteilung", als Vorläufer der heutigen Frauenklinik, errichtet.

Bis 31. Dezember 1997 war das Landeskrankenhaus Salzburg ein Regiebetrieb des Landes Salzburg, der im Wege der Anstaltenverwaltung geführt wurde. Mit Wirkung vom 1. Jänner 1998 wurde die Betriebsführung an die Holding der Landeskliniken (LKS) übertragen. Mit Wirkung vom 1. Jänner 2004 sind Rechtsträgerschaft und Betriebsführung des Landeskrankenhauses Salzburg an die Gemeinnützige Salzburger Landeskliniken Betriebsgesellschaft mbH - SALK übertragen worden.

Nach dem Zweiten Weltkrieg kam es zu einem großzügigen Ausbau des St. Johanns-Spitals. Als bislang letztes großes Bauprojekt wurde 2001 die Chirurgie West eingeweiht.

Figure 4: Screenshot of information provided on 'Landeskrankenhaus Salzburg' in SalzburgWiki (29.01.2018) (Landeskrankenhaus, 2018)

\section{Translation Figure 4 (by the author):}

Between 1891 and 1899 the first children's hospital was built, and between 1897 and 1899 the obstetrics and women's ward, a precursor of today's gynaecological clinic.

Until 31 December 1997, the Salzburg state hospital was a service provided by the state of Salzburg, managed by the state's administration. On 1 January 1998, the operational management was shifted to LKS (holding of state hospitals). Since 1 January 2004, the legal entity as well as the management of the Salzburg state hospital have belonged to SALK (Salzburg state hospital joint operating company $\mathrm{mbH}$ ).

After WWII, St. Johann's hospital underwent a major rebuild. The 'Chirurgie West' (surgical ward west), the latest major building project, was inaugurated in 2001. 


\section{Wöhset al}

\section{Information: Website - QR code}

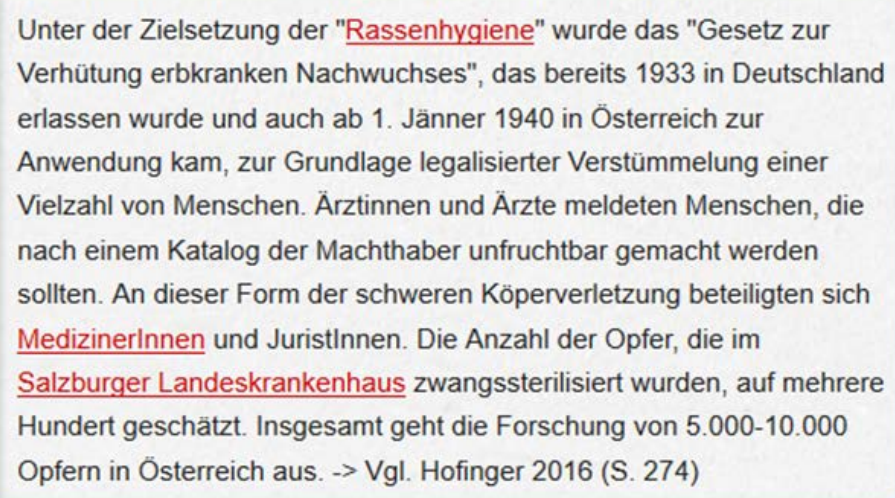

Unter der Zielsetzung der "Rassenhygiene" wurde das "Gesetz zur Verhütung erbkranken Nachwuchses", das bereits 1933 in Deutschland erlassen wurde und auch ab 1. Jänner 1940 in Österreich zur Anwendung kam, zur Grundlage legalisierter Verstümmelung einer Vielzahl von Menschen. Ärztinnen und Ärzte meldeten Menschen, die nach einem Katalog der Machthaber unfruchtbar gemacht werden sollten. An dieser Form der schweren Köperverletzung beteiligten sich Medizinerlnnen und JuristInnen. Die Anzahl der Opfer, die im Salzburger Landeskrankenhaus zwangssterilisiert wurden, auf mehrere Hundert geschätzt. Insgesamt geht die Forschung von 5.000-10.000 Opfern in Österreich aus. -> Vgl. Hofinger 2016 (S. 274)

Der Widerstand gegen diese Angriffe auf die schutzlosesten Mitglieder der Gesellschaft war sehr gering. Bekannt ist, dass die Schwestern des Ordens des HI. Vinzenz von Paul, die als Operationsassistentinnen im Landeskrankenhaus tätig waren, von ihrer Ordensleiterin Sr. Anna Bertha von Königsegg angewiesen wurden, eine Mitwirkung zu unterlassen.

Figure 5 (left) and Figure 6 (right): Screenshot of 'Ansichtssache' - Information behind the QR code (01.02.2018) (KZ-Verband, 2017)

\section{Translation of Figure 5 (by the author):}

Under the objectives of 'racial hygiene', the law for the 'prevention of genetically disordered offspring' was issued in 1933 in Germany, and later, on 1 January 1940, in Austria. This law served as the statutory basis for legalized mutilation perpetrated on many people. Doctors reported people who should be sterilized according to the Fuerher's list. It was doctors and lawyers who participated in this form of grievous bodily harm. The number of victims who were coercively sterilized at the Salzburg state hospital is estimated at several hundred. Research estimates the number of victims in the country of Austria as a whole at 5,00010,000. (See Hofinger, 2016, p. 274.)

\section{Translation of Figure 6 (by the author):}

Resistance to attacks on helpless civilians was almost non-existent. What is known is that the sisters of the Order of Saint Vincent of Paul, who assisted surgeons in sterilizing operations, were told not to participate in such undertakings. It was the supervisory nun, Sister Anna Bertha von Königsegg, who gave this order.

After extracting the new information, the next step for students is to add the missing information into the public Wiki. By doing this, the students expand the digital, open archive of SalzburgWiki and, therefore, communicate the information to the public.

In order to synthesize all new information, students are then asked to create a map in ArcGIS online where they spatialize the information of their target locations. Each student group should create one layer with all information for their location. Finally, the whole class combine their layers into one single map. Figure 7 provides a prototypical overview of the combination of all student-created layers and, as a result, of all target locations of resistance 
in Salzburg. In a real implementation, the students should include a link to their place in SalzburgWiki, a link to their source (QR code website), a short description of the location, and a picture of it.

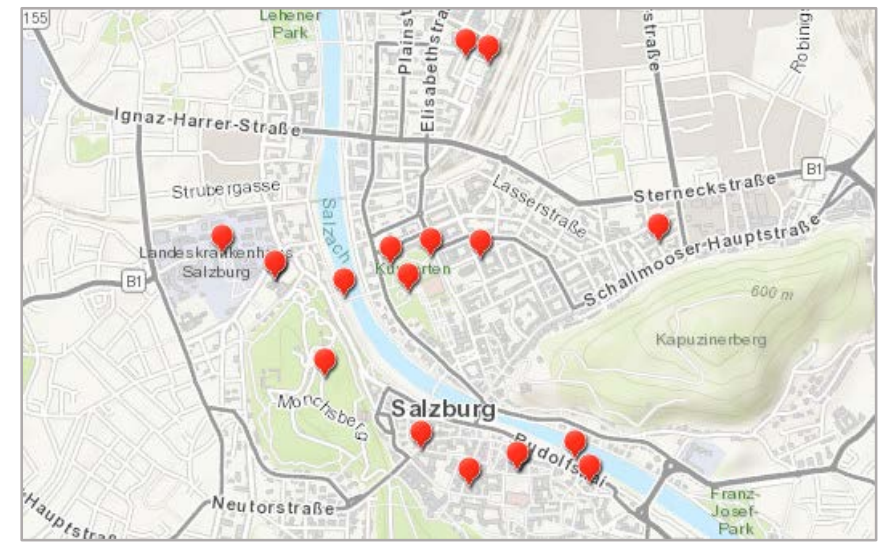

Figure 7: Tour 'Lesson 3': Arc GIS online - location map (prototype) (the author, 2018)

\section{Conclusion}

Taken as a whole, this project should promote Holocaust Education in- and outside the classroom context, through the integration and use of geomedia. The project is divided into four major steps. The first step is a given - cards designed and provided by KZ-Verband, an Austrian organization whose aim is to preserve the legacy of resistance fighters during WWII. The following three steps are new. They should promote awareness about the Holocaust in Salzburg and about acts of resistance there, as well as promote critical thinking, self-directed study, spatializing information, and the communication of information to the public. Students not only learn about the acts of resistance as such, but also that there were certain triggers which provoked them, and that resistance was and still is an option. Consequently, this approach/project serves as a novel way of learning and teaching about the Holocaust.

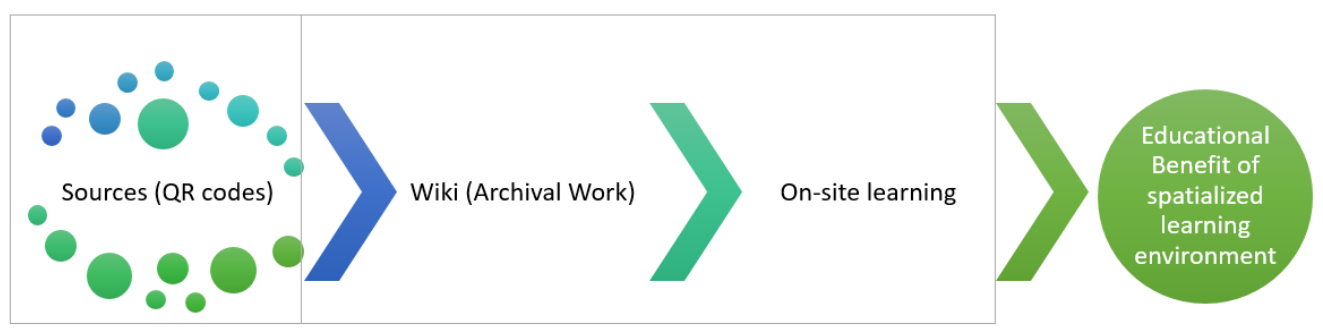

Figure 8: Summary - What was given, what is new, what will come next? (the author, 2018) 


\section{Prospects}

As the lesson plan is still at the design level only, the next step will be to conduct the project in schools and to elaborate on how it is perceived by students, notably in terms of its educational benefit. Moreover, the project could be expanded to further locations. However, since the fundamental basis of this project is the collection of cards provided by KZVerband Salzburg, which focus on places of resistance in the city of Salzburg only, some groundwork would need to be done for other places. This means that the project could not be repeated in an identical manner for other places, but it could be adapted for them. So, for example, if schools from all over Austria were working on similar projects, a map could be generated where various histories of local places could be combined into a new archive for the history of resistance during the Holocaust in Austria. This could also be done in other countries as well. Another issue to work on in the future is to maintain the students' entries in the Wiki, since it is possible that they could be deleted. Concerning the online tour, a future development might be to create a VR-tour through the places of resistance in the old town of Salzburg.

\section{Acknowledgement}

The 'Ansichtssache' cards, which include the pictures and QR codes of the places of resistance, were designed and published by KZ-Verband Salzburg.

\section{Bibliography}

BGBl. Nr. 88/1985. (2016). Semestrierter Lehrplan. Retrieved November 04, 2017, from https://www.ris.bka.gv.at/GeltendeFassung.wxe?Abfrage=Bundesnormen\&Gesetzesnummer=10 008568\&FassungVom=2017-09-01.

Ehmann, A., Kaiser, W., Lutz, T., Rathenow, H.-F., vom Stein, C., \& Weber, N. W. (1995). Praxis der Gedenkstättenpädagogik. Wiesbaden: VS Verlag für Sozialwissenschaften.

Friedländer, S. (2008). Das Dritte Reich und die Juden. München: C.H. Beck Verlag, p. 168.

Gordon, E., Elwood, S. and Mitchell, K. 2016. Critical Spatial Learning: Participatory Mapping, Spatial Histories, and Youth Civic Engagement. Children's Geographies, 558-572 doi: $10.1080 / 14733285.20151136736$.

Gryl, I. \& Jekel, T. (2012). Re-centering GI in secondary education. Towards a spatial citizenship approach. Cartographica 47,1, 18-28.

Hellmuth, T. (2016). Erinnern und vergessen - Erinnerungskultur im neuen Lehrplan der

Sekundarstufe I. In VGS (Ed.), Historische Sozialkunde: Geschichte, Fachdidaktik, Politische Bildung, pp. 1115.

Hofinger, J. (2016). Nationalsozialismus in Salz̧urg. Opfer. Täter. Gegner. Innsbruck: Studienverlag.

IHRA. Stockholm Declaration. Retrieved July 11, 2018, from

https://www.holocaustremembrance.com/stockholm-declaration.

KZ-Verband. (2012, April 27). Vereinsstatut. Retrieved February 01, 2018, from http://www.kzverband.at/?page_id $=36$.

KZ-Verband. (2017). Heilen? Retrieved February 01, 2018, from

https://www.ansichtssache.at/ansichten/heilen.html. 
Landeskrankenhaus Salzburg. (2018). In Salzburg Wiki. Salzburg, AUT. Retrieved February 1, 2018, from https://www.sn.at/wiki/Landeskrankenhaus_Salzburg.

Lehner, M., Jekel, T., Vogler, R. (2017). Flying Kites, Nazi Ideology and Collaborative Mapping: Coping with right-wing extremism in secondary education. GI_Forum, 2, 23-35. doi: 0.1553/giscience2017_02_s23.

Matthes, E. \& Meilhammer, E. (2015). Holocaust Education im 21. Jahrbundert. Bad Heilbrunn: Klinkhardt.

Ohl, U. \& Neeb, K. (2012) Exkursionsdidaktik: Methodenvielfalt im Spektrum von Kognitivismus und Konstruktivismus. In R. Duttmann, R. Glawion, H. Popp, R. Schneider-Sliwa \& A. Siegmund (Hrsg.), Geographiedidaktik (S. 259-284). Braunschweig: Westermann.

Ruep, S. (2018). Erinnerungskultur in Salzburg an den Rand gedrängt. In Der Standard. Retrieved June 18, 2018, from https://derstandard.at/2000078966131/Erinnerungskultur-in-Salzburg-an-denRand-gedraengt.

Scheidig, F. (2015). Holocaust Education und das Medium Internet: Das pädagogische Potenzial von webbasiertem Lern- und Informationsangeboten zum Holocause. in: Matthes, E. \& Meilhammer, E. (Eds.). Holocaust Education im 21. Jahrbundert. Bad Heilbrunn: Klinkhardt.

Schellenbacher, W. (2017). Memento Vienna: A Case Study in Digital Archives, Georeferenced Data and Holocaust Education. GI_Forum, 2, 13-22. doi: 10.1553/giscience2017_02_s13.

Sigel, J. (n.d.). Die International Holocaust Remembrance Alliance (IHRA) - die internationale Definition und Durchsetzung eines europäischen Geschichtsnarratives. in: Matthes, E. \& Meilhammer, E. (Eds.). Holocaust Education im 21. Jahrbundert. Bad Heilbrunn: Klinkhardt.

Welzer, H., Mollner, S., Tschuggnall, K. (2002). „Opa war kein Nari'. Nationalsozialismus und Holocaust im Familiengedächtnis. Frankfurt: Fischer Taschenbuch Verlag. 